\author{
Дойчева К.С. \\ кандидат економічних наук, старший викладач \\ E-mail: doicheva.ks@gmail.com \\ Васьковська К.О. \\ кандидат економічних наук, старший викладач \\ E-mail: v.caterin@yandex.ua \\ Пчелянська Г.Б. \\ старший викладач \\ кафедра обліку та аудиту \\ Одеська національна академія харчових технологій \\ вул. Канатна, 112, м. Одеса, Україна, 65039 \\ E-mail: gaya@te.net.ua
}

\title{
СУЧАСНІ КОМПЛЕКСНІ СИСТЕМИ ОЦІНЮВАННЯ ЕФЕКТИВНОСТІ ГОСПОДАРСЬКОЇ ДІЯЛЬНОСТІ ПІДПРИЕМСТВА
}

В статті розглянуто сутність та теоретичні основи комплексних систем управління підприємства. Здійснено аналіз концептуальних підходів щодо оцінювання ефективності - EVA (Economic Value Added, EVA). Запропоновано показник «норма доданої вартості на активи компанії» та його зворотну величину - «активоємність доданої вартості». Проаналізовано традиційні фрункції управління підприємством.

Ключові слова: оцінювання ефективності, EVA, критерії оцінювання ефективності, «норма доданої вартості на активи компанії», «активоємність доданої вартості», ранжування, система управління підприємствами, функції управління підприємством.

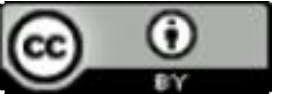

This work is licensed under a Creative Commons Attribution 4.0 International License http://creativecommons.org/licenses/by/4.0/
Постановка проблеми та її зв'язок з важливими науковими та практичними завданнями. Оцінювання ефективності діяльності підприємства має вирішальне значення при прийнятті рішень спрямованих на підвищення ефективності загалом. Оцінкою ефективності діяльності підприємств як в цілому, так і окремих аспектів його діяльності займалася велика кількість науковців, але для оцінювання ефективності діяльності промислового підприємства в цілому, потребує подальшого дослідження. Отже, для створення комплексної системи оцінювання ефективності господарської діяльності підприємства слід приділити увагу сучасним іноземним підходам щодо оцінки та управління вартістю компанії.

Аналіз останніх публікацій 3 проблеми. Значний вклад у галузь дослідження управління вартістю компанії внесли наступні іноземні науковці: Т. Коупленд, Т. Коллер, Д. Муррін, Ж. Петті, А. Раппапорт. Окремо необхідно виділити авторів, роботи яких присвячені саме концепції EVA та результатам впровадження даної концепції на практиці: Г. Біддл, Р. Боуен, С. Вивер, Б. Стюарт, Д. Янг, С. О’Бірн.

Формулювання цілей дослідження. Мета статті полягає в обгрунтуванні теоретичних аспектів щодо комплексної оцінки ефективності господарської діяльності підприємства та їх подальшого розвитку.

Виклад основних результатів і їх обгрунтування. Широко відома концепція EVA (Economic Value Added, EVA) стала фундаментом для таких ві- домих систем управління як: ринкова додана вартість (Market Value Added, MVA), грошова додана вартість (Cash Value Added, CVA) і дохідність інвестицій на основі грошового потоку (Cash Flow Return on Investment, CFROI).

Одним 3 найбільш відомих і поширених показників, призначених для оцінки вартості компанії, $\epsilon$ економічна додана вартість (Economic Value Added, EVA). Цей показник застосовують для оцінки ефективності діяльності підприємства 3 позиції його власників, який дозволяє встановити: чи приносить діяльність підприємства більший прибуток, ніж альтернативні фінансові вкладення. 3 фінансової точки зору показник EVA характеризує якість прийнятих управлінських рішень та дозволяє оцінювати як вартість компанії в цілому, так і окремих іiі підрозділів. При розрахунку EVA з суми прибутку вираховується не лише плата за користування позиковими коштами, але і власним капіталом. EVA дозволяє визначити який вид фінансування (власний або позиковий) i який розмір капіталу необхідний для одержання певного обсягу прибутку.

Отже, коли величина EVA позитивна і спостерігається позитивна динаміка цього значення, то це означає, що ефективна діяльність компанії збільшує багатство акціонерів, тоді, як від'ємне значення та негативна динаміка EVA свідчить про його зменшення і неефективність діяльності менеджменту. 
Концепція EVA часто використовується іноземними компаніями як інструмент вимірювання ефективності підрозділів замість чистого прибутку. Це пов'язано з тим, що економічна додана вартість враховує не тільки кінцевий результат (розмір отриманого прибутку), але і те, якою «ціною» він був отриманий (який обсяг капіталу на це був витрачений). EVA визначає й поведінку власників підприємства: спрямовувати капітал інвесторів у підприємство або, навпаки, сприяти їх відтоку. За допомогою показника EVA дається й оцінка ефективності господарювання через призму того, як це підприємство оцінюється ринком.

Так, існують 3 варіанти співвідношення значення показника EVA 3 поведінкою власників:

- перший варіант (EVA = 0): ринкова вартість підприємства дорівнює балансової вартості чистих активів; ринковий виграш власника при вкладенні в дане підприємство дорівнює нулю, а тому й ефективність інвестицій у це підприємство і ефективність альтернативних фінансових вкладень буде однакова;

- другий варіант (EVA > 0): приріст ринкової вартості підприємства над балансовою вартістю чистих активів стимулює власників до подальшого вкладання коштів у підприємство;

- трєтій варіант (EVA < 0): призводить до зменшення ринкової вартості підприємства; власники втрачають вкладений капітал у підприємство за рахунок втрати альтернативної прибутковості.

Якщо показник EVA обраний підприємством у якості критерію оцінки ефективності своєї діяльності, то завдання менеджерів полягає у його підвищенні, та потребує застосування відповідних заходів (табл.1).

Таблиця 1

Окремі заходи, що направлені на підвищення ефективності діяльності підприсмства*

\begin{tabular}{|c|c|}
\hline Критерії оцінки ефективності & Зростання EVA \\
\hline \multirow{3}{*}{ Мета перетворень } & - збільшення прибутку при використанні минулого обсягу капіталу; \\
\hline & $\begin{array}{l}\text { - зменшення обсягу використаного капіталу при збереженні прибутку } \\
\text { за попереднього рівня; }\end{array}$ \\
\hline & - зменшення витрат на залучення капіталу. \\
\hline \multirow{3}{*}{$\begin{array}{c}\text { Основні види організаційних } \\
\text { перетворень }\end{array}$} & $\begin{array}{c}\text { Розробка стратегії виробництва і збуту: } \\
\text { - освоєння нових видів продукції (робіт, послуг); } \\
\text { - освоєння нових ринків (нових сегментів ринку); } \\
\text { - освоєння більш рентабельних суміжних технологічних процесів. }\end{array}$ \\
\hline & $\begin{array}{l}\text { - ліквідація збиткових або недостатньо прибуткових сфер діяльності } \\
\text { (в т.ч. ліквідація підприємства); }\end{array}$ \\
\hline & - оптимізація структури капіталу підприємства. \\
\hline
\end{tabular}

* Складено авторами на підставі джерел [2-4]

Таким чином, EVA $є$ інструментом, що:

- дозволяє виміряти дійсну прибутковість підприємства, а також управляти нею з позиції його власників;

- показує керівникам підприємства, яким чином вони можуть вплинути на прибутковість;

- $\epsilon$ альтернативним підходом до концепції прибутковості (перехід від розрахунку рентабельності інвестованого капіталу (ROI), вимірюваної у процентному вираженні, до розрахунку економічної доданої вартості (EVA), вимірюваної в грошовому виpasi);

- є мотивацією менеджерів підприємства.

Таким чином, дослідження показало, що традиційні показники діяльності підприємства не повною мірою відображають його позицію на відповідних товарних ринках та здатність до стійкої конкуренції, тому запропоновано показник «норма доданої вартості на активи компанії» та його зворотну величину - «активоємність доданої вартості», що характеризують не тільки ринкову спроможність, а й дають можливість управляти більшістю внутрішніх факто- рів, що впливають на кінцевий результат, навіть розміром заробітної плати будь-якої категорії працівників підприємства.

У даній інтерпретації показник норми доданої вартості на активи та активоємність розраховуються таким чином (формули 1,2$)$ :

$$
N_{\mathrm{z}}=\frac{F+Z}{\sum_{i} A_{i}}
$$

де, $N_{B}$ - норма доданої вартості на активи компанії; $P$ - прибуток; $Z$ - заробітна плата; $A_{i}$ - вартість і-го активу компанії;

$$
E=\frac{Z\left[A_{i}\right.}{F+z}
$$

де, $E$ - активоємність господарської діяльності компанії.

Показник активоємності достатньо просто перетворюється на індексний вираз придатний для оцінки ізольованого впливу факторів на результат, та 
за рівнем управлінської придатності (коефіцієнт еластичності) дає змогу сформувати ранжировану сукупність регулюючих факторів для приведення фактичного показника норми доданої вартості до його планового чи проектного значення.

Таким чином, проведене дослідження підтвердило необхідність формування системи управління ефективністю господарської діяльності підприємства, яка являє собою процес управління, 3 урахуванням характеру цілей, принципів управління та стратегії його розвитку, який заснований на окремих функціях управління та базується на оцінці ефективності як усієї господарської діяльності, так і окремих іiї видів. Такий підхід до визначення ефективності промислових підприємств потребує розробки системи управління ефективністю його господарської діяльності.

Так, за останні 60-70 років система управління підприємствами зазнала значних перетворень, історично-великий та вагомий внесок в науку про управління внесли такі відомі вчені, як Ф.У. Тейлор, Ф. і Л. Гілбрет та Г. Гантт. Основними різноманітними концепціями управління підприємства в сучасних умовах є [3]:

- Material Requirement Planning (MRP) - система планування потреби матеріалів. Дана концепція дозволяла спланувати потребу ресурсів на підприємстві та знизити запаси. Була розроблена ще в 1950-х роках, тому для потреб теперішнього часу дана концепція MRP сильно застаріла. На сьогоднішній день, важко знайти систему управління підприємством засновану тільки на концепції MRP;

- Manufacturing Resource Planning (MRPII) концепція, що дозволяє планувати не тільки матеріальні ресурси підприємства, але також грошові і людські ресурси. Концепції MRP та MRPII зустрічаються в автоматизованих системах управління підприємством, але тільки як їх частина;

- Enterprise Resource Planning - логічний розвиток концепцій MRP та MRPII. У додавання до планування виробництва додано планування служби збуту, моделювання потоку замовлень і т.д. Системи управління підприємством класу ERP стали системами, що автоматизують усі підрозділи підприємства. Caмe ERP системи найбільш часто впроваджували компанії в 2000-х роках і саме ERP системи, а також саме їх називають «системою управління підприємством». Інакше кажучи, це змішана система управління, що отримала подальший розвиток та застосування.

На нашу думку, система управління підприємством - це певна сукупність елементів, властивості яких необхідно підбирати з урахуванням характеру цілей і принципів управління, в залежності від специфіки діяльності даного підприємства.
Сама система управління, неможлива без функцій управління. Тому, функція управління є видом управлінської діяльності, що характеризується відокремленим комплексом завдань і здійснюваним спеціальними прийомами і способами. Функції повинні мати: по-перше, чітко сформований зміст; по-друге, етапи здійснення і структуру, в рамках якої завершується іï організаційне відокремлення. Основними характеристиками функцій управління є наступні характеристики: однорідність вмісту робіт, виконуваних в рамках однієї функції; цільова спрямованість цих робіт; відокремлений комплекс завдань, які необхідно здійснити.

Традиційно, виділяють наступні функції управління (рис. 1.) [1 - 4]:

- організація виробництва - процес формування елементів і зв'язків керуючої і керованої систем, вибір методів і способів впливу як до підприємства в цілому, так і до окремих підрозділів;

- планування і прогнозування - визначається метою розвитку підприємства як на довгостроковий, так і на короткостроковий термін часу, розробкою програми, плану дій з різним ступенем деталізації, 3 розподілом на різні періоди часу; основою для вирішення завдань планування $є$ техніко-економічні показники діяльності підприємства, як в цілому по підприємству, так й його структурних підрозділів, календарно-плановий рух виробництва, ресурсне забезпечення і т.д.;

- облік, контроль і аналіз - уявляє собою встановлення, фіксування і перевірку відповідності ходу виконання виробничої програми та планових показників, виявлення, узагальнення, аналіз та оцінку, виявлення відхилень від планових показників і доведення цієї інформації до керівників підприємства, його підрозділів і функціональних служб з метою своєчасної підготовки управлінських рішень щодо регулювання процесів виробництва і реалізації продукції;

- регулювання - це процес прийняття оперативних заходів щодо усунення виявлених в процесі моніторингу i аналізу відхилень від запланованих результатів або передбачених регламентом показників;

- координація - це процес забезпечення узгодження та злагодженості в роботі виробничих і функціональних підрозділів підприємства;

- стимулювання - уявляє собою використання системи матеріального і морального стимулювання персоналу, у досягненні максимально високих результатів їх виробничої діяльності. 


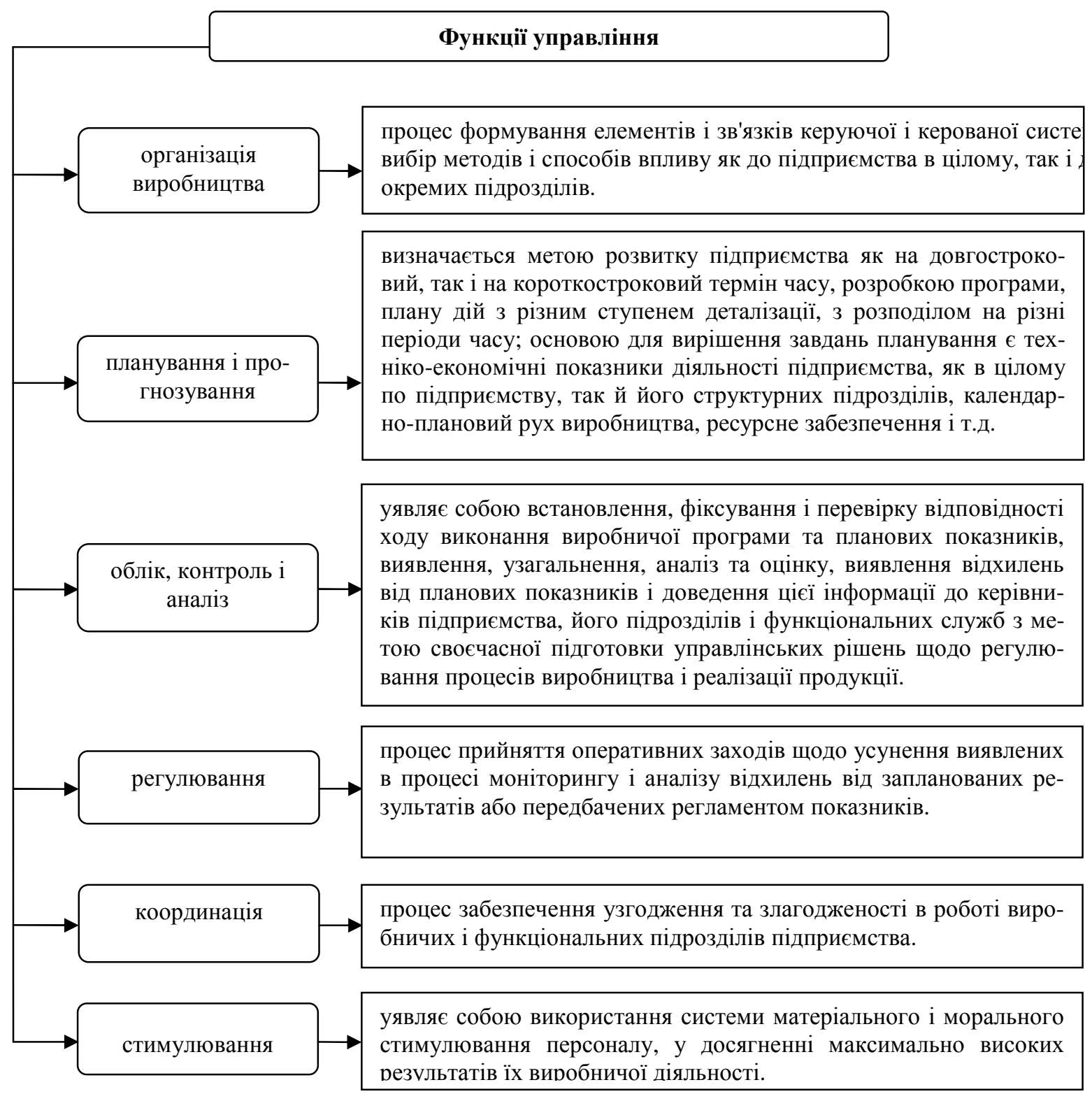

\section{Рис.1. Традиційні функції управління підприсмством* \\ * Складено авторами на підставі джерел [1-4]}

Висновки і перспективи подальших досліджень. Таким чином, підхід щодо оцінки ефективності діяльності підприємства, заснований на використанні як функцій управління, так й методичних підходів щодо іiі оцінювання надасть змогу комплексно оцінити ефективність господарської діяльності підприємства та потребує подальшої розробки та застосування системи управління нею 3 метою більш ефективного оцінювання та функціонування підприємств.

\section{Література}

1. Ансофф И. Стратегическое управление / И.Ансофф ; под ред. Л. И. Евенко; пер. с англ. - М.: Экономика, 2001. - $436 \mathrm{c.}$

2. Балабанюк Ж.М. Механізм управління організацією: сутність поняття та пропозиції щодо оцінки його ефективності [Електронний ресурс] / Ж.М. Балабанюк // Управління економічною діяльністю промислових підприємств в системі сучасних глобалізаційних процесів. - Електронний науковий журнал. - 2011. Режим доступу: http://mevhnu.at.ua/load/mizhnarodna_naukovo_praktichna_internet_konferencija/1_formuvannja_ta_ocinka_efektivnosti_funkci onuvannja_mekhanizmiv_upravlinnja_dijalnistju_pidpriemstv/2-1-0-47 
3. Система управления предприятием (ERP системы) [Електронний ресурс] / Международная консалтнговая компанія Columbus - M: Columbus, 2012. Режим доступа: http://columbusglobal.com/ruRU/Shared/Technology/RU_technonology/Business-Needs/ERP

4. Управлінський облік: [підруч для вузів] / Л.В. Нападовська. - [2-ге вид., доопрац. та допов.]. - К.: Київ нац. торг.-екон. ун-т, 2010. - 648 с.

5. Коупленд Т. Стоимость компаний: оценка и управление / Коупленд Т., Коллер Т., Муррин Дж.; пер. с англ. - М.: «Олимп-бизнесс», 1999. - 576 с.

6. Cooper S. Shareholder Wealth or Societal Welfare: A Stakeholder Perspective / Arnold G., Davies M. (eds.) Value Based Management. Context and Application. New York: Wiley\&Sons Ltd, 2000.

7. Stewart G.B. The Quest For Value: a Guide for Senior Managers. - New York: Harper Collins, 1991.

8. EVA \& Strategy II: Portfolio Management. Stern Stewart \& Co Research, The Americas, 2001.

9. EVA \& Strategy. Stern Stewart \& Co. Research, The Americas, 2000.

10. Дойчева К.С. Система оценки эффективности деятельности предприятий винодельческой промышленности / К.С.Дойчева // Социально-экономические явления и процессы: международный научнотеоретический и прикладной журнал. ФГБОУ-ВПО им. Г.Р. Державина. - Тамбов, 2013. - Вип. № 1. - С. $63-67$.

Стаття надійшла 30.10.2016

Стаття прийнята до друку 14.11.2016

Доступно в мережі Internet 30.12.2016

Дойчева К.С.

кандидат экономических наук, старший преподаватель

E-mail: doicheva.ks@gmail.com

Васьковская К.А.

кандидат экономических наук, старший преподаватель

E-mail: v.caterin@yandex.ua

Пчелянская Г.Б.

асистент, старший преподаватель

кафедра учета и аудита

Одесская национальная академия пищевых технологий

ул. Канатная, 112, г. Одесса, Украина, 65039

E-mail: gaya@te.net.ua

\section{СОВРЕМЕННЫЕ КОМПЛЕКСНЫЕ СИСТЕМЫ ОЦЕНКИ ЭФФЕКТИВНОСТИ ХОЗЯЙСТВЕННОЙ ДЕЯТЕЛЬНОСТИ ПРЕДПРИЯТИЯ}

В статье рассмотрены сущность и теоретические основы комплексных систем управления предприятия. Проведен анализ концептуальных подходов к оценке эффективности. Выделены отдельные мероприятия, направленные на повышение эффективности деятельности предприятия.

Детально рассмотрен один из самых известных и распространенных показателей, предназначенных для оценки стоимости компании - EVA (Economic Value Added, EVA). Этот показатель применяется для оценки эффективности деятельности предприятия с позиции его собственников, который позволяет установить: приносит ли деятельность предприятия большую прибыль, чем альтернативные финансовые вложения. C финансовой точки зрения показатель EVA характеризует качество принимаемых управленческих решений и позволяет оценивать как стоимость компании в целом, так и отдельных ее подразделений.

Предложен показатель «норма добавленной стоимости на активы компании» и его обратную величину - «активоемкость добавленной стоимости». Показатель активоемкости достаточно просто превращается в индексное выражение и пригоден для оценки изолированного влияния факторов на результат, а также по уровню управленческой годности (коэффицциент эластичности) позволяет сформировать ранжированную совокупность регулирующих фракторов для приведения фрактического показателя нормы добавленной стоимости к плановому или проектному значению. Проанализированы традиционные функции управления предприятием.

Ключевые слова: оценка эффективности, EVA, критерии оценки эффрективности, «норма добавленной стоимости на активы компании», «активоемкость добавленной стоимости», ранжирование, система управления предприятиями, функции управления предприятием. 


\author{
Doycheva K. \\ PhD, Assistant \\ E-mail: doicheva.ks@gmail.com \\ Vaskovska K. \\ $\mathrm{PhD}$, Assistant \\ E-mail:v.caterin@yandex.ua \\ Pchelyanskaya G. \\ Assistant \\ Department of Accounting and Auditing \\ Odessa National Academy of Food Technologies \\ Kanatna str., 112, Odessa, Ukraine, 65039ologies \\ Kanatna str., 112, Odessa, Ukraine, 65039 \\ E-mail: gaya@te.net.ua
}

\title{
MODERN INTEGRATED SYSTEM ASSESSMENT EFFICIENCY ECONOMIC ACTIVITIES OF ENTERPRISES
}

The article deals with the essence and the theoretical basis of complex enterprise management systems. The analysis of conceptual approaches to evaluating the effectiveness. Allocated separate activities aimed at increasing efficiency of the enterprise.

Detail is considered one of the most famous and common indicators to assess the company's valueEVA (Economic Value Added, EVA). This index is used to assess the effectiveness of the enterprise from the position of its owners, which allows to establish whether the activities of the enterprise brings great profit than alternative investments. From a financial point of view, EVA index characterizes the quality of management decisions and allows to evaluate the cost of the company as a whole and its individual divisions.

Proposed indicator "norm of value added to the company's assets" and its reciprocal magnitude "active-capacitance added value." Indicator active-capacitance simply enough turns into an expression of the index and is suitable for the evaluation of the isolated influence of factors on the result, as well as on the level of the management validity (elasticity factor) allows to generate a ranked set of regulatory factors to bring the actual rate of value added indicator to planned or design value. Analyzed the traditional enterprise management functions.

Keywords: performance evaluation, the EVA, performance benchmarks, "the rate of value added to the company's assets", " active-capacitance added value" ranking, enterprise management system, the enterprise management functions.

\section{References}

1. Ansoff, Y. (2001) Stratehycheskoe Upravlenye. M.: Эkonomyka.

2. Balabaniuk, Zh. M. "Mekhanizm Upravlinnia Orhanizatsiieiu: Sutnist Poniattia Ta Propozytsii Shchodo Otsinky Yoho Efektyvnosti." Upravlinnia Ekonomichnoiu Diialnistiu Promyslovykh Pidpryiemstv v Systemi Suchasnykh Hlobalizatsiinykh Protsesiv., (2011). Retrieved 2016, from http://mevhnu.at.ua/load/mizhnarodna_naukovo_praktichna_internet_konferencija/1_formuvannja_ta_ocinka_efektivnosti_funkci onuvannja_mekhanizmiv_upravlinnja_dijalnistju_pidpriemstv/2-1-0-47

3. Systema upravlenyia predpryiatyem (ERP systemu). (2012). Retrieved 2016, from http://columbusglobal.com/ru-RU/Shared/Technology/RU technonology/Business-Needs/ERP

4. Napadovska, L. V. (2010). Upravlinskyi oblik. K.: Kyiv nats.. torh.-ekon. un-t.

5. Kouplend, T., Koller, T., \& Murryn, D. (1999). "Stoymost kompanyi: Otsenka y upravlenye" M.: Olympbyzness.

6. Cooper, S., Arnold, G., \& Davies, M. (2000). Shareholder Wealth or Societal Welfare: A Stakeholder Perspective. Wiley\&Sons Ltd,: Value Based Management. Context and Application.

7. Stewart, G. B. (1991). The Quest For Value: A Guide for Senior Managers. New York: Harper Collins.

8. EVA \& Strategy II: Portfolio Management. Stern Stewart \& Co Research (2001), The Americas.

9. EVA \& Strategy. Stern Stewart \& Co. Research (2000) The Americans.

10. Doicheva, K. S. (2013). Systema otsenky эffektyvnosty deiatelnosty predpryiatyi vynodelcheskoi prombshlennosty. Sotsyalno-эkonomycheskye Yavlenyia Y Protsessы, 1, 63-67. 